Estradiol and stilbostrol act for approximately the same time and their period of action is a little longer than that of triphenyl ethylene.

Department of Pharmacology,

$$
\text { J. M. Robson. }
$$

University of Edinburgh.

\section{A. SCHÖNBERG.}

Hussein Ahmad Fahim.

Department of Chemistry,

Egyptian University,

Cairo.

July 11 .

${ }^{1}$ Robson, J. M., and Schönberg, A., Nature, 140, 196 (1937).

${ }^{2}$ Robson, J. M., Proc. Soc. Exp. Biol. N.Y., 38, 153 (1938).

${ }^{3}$ Miescher, K., Schweiz. Med. W schr., 67, 1046 (1937).

- Dodds, E. C., Golberg, L., Lawson, W., and Robinson, R., Nature, 141, 247 (1938).

${ }^{5}$ Robson, J. M., Quart. J. Exp. Physiol. (in the Press).

\section{Inhibiting Effect of Sodium Chloride on the Oxidation of Ascorbic Acid}

It was recently shown that sodium chloride $(0 \cdot 1 M)$ at $p H 7 \cdot 0$ has an inhibiting effect on the oxidation of ascorbic acid1,2. Kellie and Zilva ${ }^{2}$ showed in one experiment that sodium chloride $(0.1 M)$ inhibited the catalytic power of copper at $p \mathrm{H} 7 \cdot 0$, but Barron et $a l .^{3}$ did not succeed in demonstrating the same effect at $p \mathrm{H} 6 \cdot 0$. If it is true that sodium chloride has an inhibiting effect on the oxidation, it may be of the greatest domestic importance, for it has always been the practice of man to add salt (primitive people used sea water) to the water used for cooking meat and vegetables.

Experimental. Potatoes, cabbage and ox liver were cooked in glass-distilled water with and without addition of sodium chloride at a concentration of 1 per cent. Potatoes were cooked 45 minutes, cabbage and ox liver 20 minutes. The foodstuffs were added to the water after boiling had started. $10 \mathrm{gm}$. material was cooked with $200 \mathrm{ml}$. water. The foodstuffs were ground up with quartz and in 10 per cent trichloracetic acid and analysed by the method of Emmerie and van Eekelen ${ }^{4,5}$. In the table the numbers are the results of double analyses made on different materials. They are given as percentages of the original content of ascorbic acid in the raw substance.

\begin{tabular}{|c|c|c|c|c|c|c|}
\hline & \multicolumn{3}{|c|}{ Cooked in distilled water } & \multicolumn{3}{|c|}{$\begin{array}{l}\text { Cooked in distilled water } \\
\text { with } 1 \text { per cent sodium } \\
\text { chloride }\end{array}$} \\
\hline & $\begin{array}{l}\text { In sub- } \\
\text { stance } \\
\%\end{array}$ & $\begin{array}{c}\text { In water } \\
\%\end{array}$ & $\begin{array}{c}\text { Total } \\
\%\end{array}$ & $\begin{array}{l}\text { In sub- } \\
\text { stance } \\
\%\end{array}$ & $\begin{array}{c}\text { In water } \\
\%\end{array}$ & $\begin{array}{c}\text { Total } \\
\%\end{array}$ \\
\hline $\begin{array}{l}\text { Peeled } \\
\text { potatoes }\end{array}$ & 93 & $13 \cdot 5$ & $106 \cdot 5$ & 107 & 17 & 124 \\
\hline Cabbage & 54 & $20 \cdot 5$ & $74 \cdot 5$ & $32 \cdot 5$ & 56 & $88 \cdot 5$ \\
\hline $0 x$ liver & 46 & 44 & 90 & 38 & 52 & 91 \\
\hline
\end{tabular}

Thus we find 16-19 per cent more ascorbic acid left when vegetables are cooked in salt solution than in vegetables cooked in distilled water. In agreement with McHenry and Graham ${ }^{6}$, we found considerably more ascorbic acid in cooked than in raw potatoes. These authors claimed that ascorbic acid in raw vegetables were partially fixed as esters which are hydrolysed by cooking. Van Eekelen ${ }^{7}$ repeated their experiments with another technique using 3 per cent trichloracetic acid for the grinding medium, and found that potatoes, in fact, lost ascorbic acid by cooking; he explained the remarkable results of McHenry and Graham as being due to action of enzymes during the grinding process. In our experiments such an action of enzymes is excluded, since we used strong trichloracetic acid as grinding medium. We know of no other observations suggesting that ascorbic acid in vegetables is fixed in the form of esters. In our opinion, the phenomenon is easily explained by the fact that it is very difficult to extract ascorbic acid quantitatively from raw vegetables, especially when strong trichloracetic acid is used, and the extraction has to be done quickly in order to avoid destruction of the ascorbic acid.

The main purpose with this communication, how. ever, is to point out that vegetables cooked in water containing sodium chloride appear to keep their ascorbic acid better than vegetables cooked in distilled water.

\section{Institute of Physiology, \\ A. HøygaARd.} University, Oslo. July 8.

Caro, de, L., and Giani, M., Z. phys. Chemie, 228, 13 (1934).

Kellie, A. E., and Zilva, S. S., Biochem. J., 29, 1028 (1935).

${ }^{3}$ Barron, E. S. G., De Meio, R. H., and Klemperer, F., J. Biol. Chem. $112,625(1935-36)$.

${ }^{1}$ Emmerie, A., and Eekelen, M. van, Biochem. J., 28, 1153 (1934).

${ }^{5}$ Emmerie, A., Biochem. J., 28, 268 (1934).

6 McHenry, E. W., and Graham, M. L., NATURE, 135, 871 (1935).

' Eekelen, M. van, Nature, 136, 144 (1935).

\section{Regeneration of Root Cuttings as Influenced by Plant Hormones}

Root cuttings (thongs) of sea-kale (Crambe maritima) under suitable conditions produce, whichever way up they are inserted in the rooting medium, buds and roots at the morphological apex (proximal end) and base (distal end) respectively (Fig. $C$ ). This phenomenon of polarity has been explained by Went and Thimann in terms of the polar transport of auxin-"polarity can now be expressed quantitatively as a function of the transport of a known substance in the tissues"'.

Experiments here tended to suggest that the production of buds and roots is possibly dependent on the local concentration of growth substances within the tissues. Thongs $7 \mathrm{~cm}$. in length were used. The morphological apices were treated for 20 hours with a solution of $\alpha$-naphthalene-acetic acid ( 0.02 per cent). After 14 days, roots had been produced both apically and basally (Fig. $A$ ). The length of the roots varied from $1 \mathrm{~cm}$. to $5 \mathrm{~cm}$. No buds were produced at the apex. These observations implied that under normal conditions the presence of a relatively high but quantitative amount of growth substance determines the production of roots. Bud production, on the other hand, may be associated with a relatively low concentration of growth substance. Proof of this would lie in the production of buds basally as well as apically. Thus, assuming the polar transport of auxin from all regions to the base, it would be necessary to remove this accumulating auxin and therefore lower the concentration at the base. A possible method of achieving this lay in washing the thongs in running water for 48 hours, but this produced no effect upon the subsequent behaviour of the cuttings. A second method which eventually proved successful was to remove approximately a millimetre of tissue from the base and apex of the thongs every five 